\title{
Resiko Jatuh pada Klien Stroke yang Menggunakan Kursi Roda di Kabupaten Pamekasan
}

\author{
Abdan Syakura ${ }^{1 *}$, Aghniya Nisa'asy Shobiri $\mathrm{NHJ}^{2}$, Anggeria Oktavisa Denta ${ }^{3}$ \\ 1,2,3 Politeknik Negeri Madura \\ 1'abdansyakura@poltera.ac.id“" ${ }^{2}$ anggie.oktavisa@gmail.com, ${ }^{3}$ aghniyanhj@gmail.com \\ *Corresponding author
}

\begin{tabular}{ll}
\hline Informasi artikel & ABSTRAK \\
\hline Sejarah artikel: & Penderita stroke dengan immobilisasi rata-rata menggunakan kursi roda \\
Received: $10-08-2021$ & untuk membantunya berpindah/ber aktivitas sehari-hari, sehingga \\
Revised: 18-11-2021 & kemungkinan akan berisiko mengalami jatuh selama pengoperasiannya. \\
Accepted: 22-11-2021 & Tujuan penelitian ini untuk mengetahui gambaran risiko jatuh pada \\
\hline Kata kunci: & klien stroke yang menggunakan kursi roda di Kabupaten Pamekasan. \\
Keamanan, Kursi Roda & Metode: Rancangan dalam karya tulis ini menggunakan desain deskriptif \\
Mobilisasi, Stroke & cross sectional. Populasi pada penelitian ini sebanyak 31 orang klien \\
& stroke pengguna kursi roda di Kabupaten Pamekasan dengan tehnik \\
& pengambilan sampel menggunakan total sampling. Penelitian \\
& dilaksanakan di wilayah Kabupaten Pamekasan pada bulan Februari \\
& 2021. Pengumpulan data dilakukan dengan memberikan kuesioner jenis \\
& Close ended-Multiple choice question dengan menggunakan skala \\
& ordinal memuat 12 item pertanyaan dan kemudian dilakukan \\
& pengolahan data berupa editing, scoring, coding, tabulating. Hasil: \\
& Sebagian besar responden yang telah diteliti mengalami risiko jatuh \\
& rendah sebanyak 14 orang (45\%). Kesimpulan: Keluarga diharapkan \\
& mempertahankan pemberian bantuan dan pengawasan terhadap \\
& penderita stroke, terutama pada penderita yang sudah pernah jatuh.
\end{tabular}

Key word:

Mobilization, Safety, Stroke, Wheelchair

\begin{abstract}
Description of Falling in Stroke Clients Who Use Wheelchair in Pamekasan District. Introduction: people who suffer from stroke and immobilization use wheelchair to help move/carry out daily activities on average, so they may be at risk of falling during its usage. This research aimed to comprehend the fall risk assessment in stroke clients with wheelchair at RSUD Dr. H. Slamet Martodirdjo Pamekasan. Methods: This research used a cross sectional descriptive design. Population in this research was 31 stroke clients using wheelchairs in Pamekasan District with the sampling technique using total sampling. This research was conducted in the region of Pamekasan on February, 2021. Data was collected by distributing a Close ended-Multiple choice questionnaire with an ordinal scale containing of 12 question items and then processing the data in the form of editing, scoring, tabulating. Results: Most of the total respondents who have been researched indicate a low risk of falling as 14 people (45\%). Conclusion: The Families are expected to provide assistance and supervision to stroke client, especially those who have experienced falling.
\end{abstract}

\section{PENDAHULUAN}

Pasien stroke dengan immobilisasi akibat hemiplegia atau hemiparesis membutuhkan dukungan ambulasi (memfasilitasi pasien untuk berpindah), alat yang sering digunakan di rumah sakit yakni kursi roda (Nursyiham et al., 2019). Kondisi pasien stroke yang tidak stabil, mengalami kelemahan, dan atau kelumpuhan anggota gerak membutuhkan alat bantu berupa kursi roda khusus serta pelayanan dan pemantauan yang lebih guna memenuhi keamanan pasien (Pratiwi et al., 2019). Jenis kursi roda yang digunakan di rumah sakit daerah Kabupaten Pamekasan selama ini menggunakan kursi roda standar yang 
umum digunakan oleh semua kalangan pengguna yang tentunya kurang sesuai dengan kondisi penderita penyakit tertentu misalnya pada penderita stroke.

Penderita stroke dari tahun ke tahun semakin meningkat. Prevalensi pasien stroke menurut data Rikesdas tahun 2013 diperoleh jumlah penderita stroke di provensi Jawa Timur sebanyak 507 orang penderita dengan Persentase penduduk stroke sebanyak 1,4\% di daerah Kabupaten Pamekasan (Istichana, 2015). Data penderita stroke menurut World Health Organization (WHO) pada tahun 2015 secara global terdapat sebanyak 15 juta orang terkena stroke dan sekitar 5 juta orang menderita kelumpuhan permanen. Data penderita stroke menurut World Stroke Organization (WSO) pada tahun 2016 terdapat 13,7 juta kasus baru stroke setiap tahun. Data hasil Riskesdas 2018 secara nasional, prevalensi stroke di Indonesia meningkat dari jumlah 7\% pada tahun 2013 menjadi 10,9\% pada tahun 2018 atau diperkirakan sebanyak 2.120.362 orang (Kemenkes, 2019). Penderita stroke di rumah sakit umum daerah Dr. H. Slamet Martodirdjo tahun 2018 terdapat 5,55\% dari total kasus/penyakit yang ada dengan jumlah 348 orang penderita stroke (RSUD Pamekasan, 2018). Penderita stroke di rumah sakit umum daerah Dr. H. Slamet Martodirdjo tahun 2020 terdapat sebanyak 177 orang, dengan jumlah penderita di daerah Kabupaten Pamekasan sebanyak 134 orang (RSUD Pamekasan, 2020).

Pasien stroke sebanyak 80\% akan mengalami hemiplegia atau hemiparesis yang berarti satu sisi lemah atau bahkan lumpuh (Basuki, 2018). Pasien dengan kondisi pascastroke atau stroke akan menyerang sistem saraf sehingga terjadi penurunan fungsi sistem saraf yang menyebabkan sering terjadi penurunan kesadaran secara tiba-tiba yang menyebakan pasien pingsan atau bahkan kelelahan/tertidur, dan berdampak juga pada alat gerak tubuh seperti kaki dan tangan yang tiba-tiba mengalami kelumpuhan/kelemahan secara mendadak yang menyebabkan pergerakannya menjadi terbatas atau bahkan tidak dapat digerakkan sama sekali dan kerap menimbulkan rasa nyeri jika dipaksa untuk bergerak di atas ambang batas, sehingga dapat mempengaruhi Activity of Daily Living (ADL) penderitanya (Karunia, 2016). Pasien dengan serangan pascastroke/stroke rata-rata akan menggunakan alat bantu kursi roda untuk mempermudah dalam memenuhi ADL-nya, dengan kondisi yang tidak stabil tersebut tentunya akan sangat berisiko mengalami cidera fisik baik pada pasien itu sendiri atau orang lain yang membantunya menggunakan kursi roda misalnya sulit melakukan transfer dari tempat tidur ke kursi roda, jika pasien tertidur/kelelahan akan merasa tidak nyaman karena tidak ada sandaran kepala, dan bahkan saat terjadi pingsan posisi tubuhnya akan bergeser dan bahkan jatuh dari kursi roda/kepala akan terjatuh kebelakang yang dapat menyebabkan cidera pada tulang leher, tangan yang mengalami kelelahan atau kelumpuhan mendadak sehingga jatuh dari pegangan kursi roda dan begitupun pada kaki yang bisa saja jatuh dari pijakan kaki kursi roda sehingga menimbulkan luka lecet atau pergeseran sendi, dan pada orang yang membantu pasien menggunakan kursi roda kemungkinan juga akan mengalami cidera jika pasien sewaktu-waktu tertidur/pingsan saat menggunakan kursi roda sehingga tidak dapat menahan beban pasien terutama ketika melewati lorong yang menurun atau menanjak sehingga kemungkinan besar akan jatuh.

Solusi untuk permasalahan yang telah dijabarkan tersebut diperlukan adanya pemantauan terhadap mobilisasi pasien stroke/pascastroke dengan dilakukan observasi sesering mungkin terhadap kondisi pasien, kemampuan mobilisasi, kemampuan penggunaan alat mobilisasi, serta keamanan yang dirasakan selama penggunaan fasilitas mobilisasi (kursi roda) yang digunakan yaitu dari risiko jatuh.

\section{METODE PENELITIAN}

Rancangan dalam karya tulis ini menggunakan desain deskriptif cross sectional. Populasi pada penelitian ini sebanyak 31 orang klien stroke pengguna kursi roda di Kabupaten Pamekasan dengan tehnik pengambilan sampel menggunakan total sampling. Penelitian dilaksanakan di wilayah Kabupaten Pamekasan pada bulan Februari 2021. Pengumpulan data dilakukan dengan memberikan kuesioner jenis Close ended-Multiple choice question dengan menggunakan skala ordinal memuat 12 item pertanyaan dan kemudian dilakukan pengolahan data berupa editing, scoring, coding, tabulating 


\section{HASIL DAN PEMBAHASAN}

Kabupaten Pamekasan memiliki puskesmas pada setiap kecamatannya dengan total 20 puskesmas yang dapat merujuk pasiennya dengan kondisi yang tidak dapat ditangani ke rumah sakit umum Dr. H. Slamet Martodirdjo, salah satunya pada pasien penderita stroke. Penderita stroke pada tahun 2020 di rumah sakit umum Dr. H. Slamet Martodirdjo tercatat sebanyak 134 orang (78 laki-laki dan 56 perempuan) penderita stroke di daerah Kabupaten Pamekasan, dengan jumlah penderita stroke pengguna kursi roda di daerah Kabupaten pamekasan sebanyak 31 orang (RSUD Pamekasan, 2020).

Tabel 1 Distribusi responden berdasarkan usia.

\begin{tabular}{llcc}
\hline No & Usia & F & \% \\
\hline 1 & $36-53$ & 8 & $26 \%$ \\
\hline 2 & $54-71$ & 16 & $52 \%$ \\
\hline 3 & $72-90$ & 7 & $23 \%$ \\
\hline \multicolumn{2}{l}{ Total } & 31 & $100 \%$ \\
\hline
\end{tabular}

Sumber: Data primer 2021

Tabel 1 menunjukkan bahwa setengah dari seluruh responden yang diteliti terdapat sebanyak 16 orang (52\%) berusia di antara 54-71 tahun dan sebagian kecil dari seluruh responden yang diteliti terdapat sebanyak 7 orang (23\%) berusia di antara 72 90 tahun.

Tabel 2

Distribusi responden berdasarkan jenis kelamin.

\begin{tabular}{lllc}
\hline No & Jenis Kelamin & F & \% \\
\hline 1 & Laki-laki & 17 & $55 \%$ \\
\hline 2 & Perempuan & 14 & $45 \%$ \\
\hline \multicolumn{2}{l}{ Total } & 31 & $100 \%$ \\
\hline
\end{tabular}

Sumber: Data primer,2021

Tabel 2 menunjukkan bahwa sebagian besar responden sebanyak 17 orang (55\%) berjenis kelamin laki-laki dan hampir setengah dari seluruh responden sebanyak 14 orang (45\%) berjenis kelamin perempuan.
Tabel 3 responden
Distribusi berdasarkan
frekuensi terakhir.

\begin{tabular}{llcc}
\hline No & Pendidikan & F & \% \\
\hline 1 & Tidak Sekolah & 8 & $26 \%$ \\
\hline 2 & SD & 18 & $58 \%$ \\
\hline 3 & SMP/MTS & 0 & $0 \%$ \\
\hline 4 & SMA/SMK/MA & 3 & $10 \%$ \\
\hline 5 & PT & 2 & $6 \%$ \\
\hline & Total & 31 & $100 \%$ \\
\hline
\end{tabular}

Sumber: Data primer,2021
Tabel 3 menunjukkan bahwa sebagian besar responden sebanyak 18 orang (58\%) memiliki pendidikan terakhir sampai sekolah dasar (SD), terdapat hampir setengah dari seluruh responden sebanyak 8 orang (26\%) tidak sekolah dan sebagian kecil dari seluruh responden sebanyak 3 orang (10\%) memiliki pendidikan terakhir sampai sekolah menengah atas (SMA)/sekolah menengah kejuruan (SMK)/madrasah aliah (MA) dan 2 orang (6\%) memiliki pendidikan terakhir sampai perguruan tinggi (PT).

Tabel 4 Distribusi responden berdasarkan pekerjaan

\begin{tabular}{clcc}
\hline No & Pekerjaan & F & \% \\
\hline 1 & Tidak bekerja & 30 & $97 \%$ \\
\hline 2 & Swasta & 1 & $3 \%$ \\
\hline 3 & Wirausaha & 0 & 0 \\
\hline 4 & PNS & 0 & 0 \\
\hline 5 & TNI/POLRI & 0 & 0 \\
\hline \multicolumn{2}{l}{ Total } & 31 & $100 \%$ \\
\hline
\end{tabular}

Sumber: Data primer,2021

Tabel 4 menunjukkan bahwa hampir seluruh responden sebanyak 30 orang (97\%) tidak bekerja dan sebagian kecil sebanyak 1 orang (3\%) bekerja sebagai swasta.

Tabel $5 \quad$ Distribusi frekuensi responden berdasarkan risiko jatuh pada klien stroke yang menggunakan kursi roda.

\begin{tabular}{clcc}
\hline No & Interpretasi & $\mathbf{F}$ & $\mathbf{\%}$ \\
\hline 1 & Risiko tinggi & 7 & $23 \%$ \\
\hline 2 & Risiko sedang & 10 & $32 \%$ \\
\hline 3 & Risiko rendah & 14 & $45 \%$ \\
\hline \multicolumn{2}{l}{ Total } & 31 & $100 \%$ \\
\hline
\end{tabular}

Sumber: Data primer,2021

Tabel 5 menunjukkan bahwa hampir setengah dari seluruh responden yang diteliti terdapat sebanyak 14 orang (45\%) dan sebanyak 7 orang (23\%) berisiko tinggi untuk mengalami jatuh dari kursi roda.

\section{PEMBAHASAN}

Penelitian yang telah dilakukan diketahui bahwa penderita stroke pengguna kursi roda yang berisiko mengalami jatuh dari kursi roda dapat disebabkan oleh beberapa faktor sebagai berikut:

1. Aktivitas pengguna

Peneliti menemukan bahwa tingkat aktivitas responden sebagian besar tidak melakukan aktivitasnya di luar rumah dan hampir setengah dari keseleruhan jumlah responden melakukan aktivitas dengan menggunakan kursi roda di luar rumah 
atau ruangan sesuai kuesioner item pertanyaan nomor 1 . Hambatan mobilitas fisik pada penderita stroke dapat dibantu dengan menggunakan alat untuk melakukan ambulasi seperti kursi roda (Pratama, 2020). Menurut penelitian yang dilakukan oleh I Made Londen Batan (2006) Kursi roda dapat digunakan untuk beraktivitas di dalam atau luar rumah, namun kursi roda yang terjual dipasaran kurang nyaman/kesulitan untuk dibawa bekerja dan beraktivitas di luar ruangan terutama jika dioperasikan secara mandiri, serta tidak dapat digunakan sebagai tempat istirahat. Hal ini yang menjadi faktor penyebab responden lebih banyak menggunakan kursi roda di dalam rumah daripada di luar rumah yaitu ketidakmampuan mengoperasikan kursi roda secara mandiri dan sudah tidak bekerja sesuai dengan data yang diperoleh dari hasil jawaban kuesioner responden, sedangkan pada pengguna kursi roda yang yang masih melakukan aktivitas di luar rumah untuk berjemur atau jalan-jalan di sekitar rumah. Menurut penelitian yang dilakukan oleh Suhendro (2014) berjemur antara jam 07.30 - 08.30 pagi memiliki manfaat untuk menyembukan penyakit stroke, penelitian lainnya oleh Kurniasih \& Pratama (2020) menyatakan bahwa berjemur dibawah sinar matahari dapat meningkatkan daya tahan tubuh. Penelitan ini tidak dilakukan wawancara atau survey lebih mendalam tentang alasan responden beraktivitas hanya di dalam ruangan/rumah saat menggunakan kursi roda dan alasan responden beraktivitas di luar rumah saat menggunakan kursi roda, karena penelitian ini berfokus pada penyebab terjadinya risiko jatuh pada penderita stroke pengguna kursi roda.

Peneliti menemukan bahwa sebagian besar responden sudah tidak ke kamar mandi untuk buang air besar (BAB) dan atau buang air kecil (BAK) sesuai kuesioner item pertanyaan soal nomor 2 . Rancangan rumah untuk penyandang cacat fisik terutama yang menggunakan kursi roda tidak harus seperti rumah sakit namun harus disesuaikan dengan kebutuhan sehingga mempermudah akses seperti halnya pada desain kamar mandi (memiliki ruang sirkulasi) agar terdapat ruang untuk gerakan tubuh dan kursi roda, persyaratan untuk akses ke kamar mandi/toilet untuk pengguna kursi roda ukuran minimum ruang harus 2,40 $\mathrm{m} \mathrm{X} \mathrm{2,30} \mathrm{m}$, tinggi $\mathrm{WC} 0,48$ $\mathrm{m}$ diatas lantai, lebar $\mathrm{WC} 0,80 \mathrm{~m}$, tinggi wastafel $0,80 \mathrm{~m}$ di atas lantai, dan lebar wastafel 0,60 m (Ambarwati, 2009). Dilihat dari teori dan hasil jawaban kuesioner responden diketahui terdapat hubungan penyebab sebagian besar responden tidak ke kamar mandi/toilet lagi untuk melakukan aktivitas BAK/BAB ke kamar mandi karena kemungkinan desain kamar mandi yang ada di rumah tidak mendukung untuk pengguna kursi roda sehingga merasa kesulitan, sedangkan sebagian responden yang masih dapat ke kamar mandi kemungkinan besar kondisi kamar mandi sesuai untuk pengguna kursi roda seperti yang dipaparkan pada teori atau diangkat oleh keluarga untuk ke kamar mandi dan menggunakan WC duduk. Saat memandikan penderita stroke yang menyandang cacat kaki harus di bopong/mengangkat pasien dari kursi roda ke kursi khusus di kamar mandi dan setelah selesai mandi harus di angkat kembali ke kursi roda (Purwanggono, Inryani, \& Adi, 2008). Orang pasca stroke/stroke disarankan menggunakan toilet duduk atau pispot guna menghindari kecelakaan saat BAK/BAB seperti terjatuh dan merasa nyeri di kaki secara tiba-tiba (Karunia, 2016).

\section{Bantuan orang lain \\ Peneliti menemukan bahwa sebagian} besar responden yang ada di rumah aktivitasnya dibantu oleh keluarga terutama saat berpindah dari tempat tidur ke kursi roda atau sebaliknya sesuai kuesioner item pertanyaan soal nomor 3. Penderita stroke pengguna kursi roda diharapkan memiliki kemampuan ambulasi dengan menggunakan kursi roda, yaitu kemampuan berpindah secara mandiri atau dibantu oleh keluarga : dari tempat tidur ke kursi roda dan sebaliknya, berpindah dari kursi roda ke kendaraan dan sebaliknya, berpindah dari kursi roda ke toilet dan sebaliknya (Pratama, 2020). Bantuan keluarga di rumah bagi pengguna kursi roda dapat dilakukan oleh pihak keluarga atau dari caregiver terutama pada kondisi klien yang mengalami kelumpuhan total yang membutuhkan bantuan penuh atau pada penderita hemiplegia, sebelum klien dipulangkan dari rumah sakit akan dilakukan pemantauan dan pemeriksaan terhadap kondisi tubuh dan keluarga akan diberikan edukasi berupa cara memindahkan kien dari tempat tidur ke kursi roda atau sebaliknya untuk 
meminimalisir terjadinya kecelakaan berupa risiko jatuh (Karunia, 2016). Berdasarkan hasil survey di lapangan (peneliti melihat langsung penderita stroke ketika dipindahkan ke kursi roda dan berpindah secara mandiri ke kursi roda) diketahui adanya persamaan dengan teori sehingga sebagian besar responden dibantu oleh keluarga untuk berpindah dari tempat tidur ke kursi roda atau sebaliknya kemungkinan karena ekstremitas responden masih lemah/tidak bisa digerakkan/takut untuk bergerak, sedangkan hampir setengah dari keseluruhan jumlah responden yang ada dapat mandiri dalam berpindah kemungkinan karena ekstremitasnya dapat digerakkan meskipun masih lemah (hampir mengalami pemulihan)/penderita stroke tidak sampai mengalami gangguan ekstremitas yang parah berupa kaku otot dan sendi (hanya mengalami kelemahan) sehingga masih mampu untuk menompang tubuhnya meski sesaat hanya untuk berpindah. Kemandirian penderita stroke dalam memenuhi kebutuhan dasar Activity Of Daily Living (ADL) selain dipengaruhi oleh kondisi fisiknya juga sangat dipengaruhi oleh dukungan, motivasi, dan keputusan keluarga dalam menerapkan latihan motorik dan kemandirian kepada anggota keluarga yang mengalami stroke seperti makan, minum, menggunakan alat bantu jalan dan membersihkan diri guna menghindari komplikasi berupa semakin parahnya gangguan fungsional tubuh terutama pada ekstremitas berupa kekakuan otot dan sendi bahkan atropi otot (Karunia, 2016). Peran keluarga dalam memenuhi kebutuhan aktivitas responden terutama dalam toileting dan penggunaan kursi roda sebagian besar sudah terpenuhi terbukti dengan jawaban pada kuesioner item pertanyaan nomor 2 dan 3 . Kemandirian merupakan suatu keadaan yang dibutuhkan dan dibentuk tidak hanya oleh diri snediri tapi juga dengan bantuan orang lain (Syakura \& Sw, 2020).

\section{Kondisi lingkungan}

Peneliti menemukan bahwa sebagian besar kondisi lingkungan tempat tinggal yang dilewati oleh kursi roda sebagian besar tidak terdapat tangga/pembatas lantai antar ruangan/jalan landai/jalan licin sesuai kuesioner item pertanyaan soal nomor 4. Penyandang disabilitas terutama cacat kaki memerlukan alat bantu untuk berjalan seperti kursi roda untuk membantunya melakukan aktivitas sehingga kondisi lingkungan harus disesuaikan agar dapat dilalui dengan aman baik yang ada di luar ruangan maupun di dalam ruangan yaitu membutuhkan permukaan jalan datar, kuat, stabil, tahan terhadap perubahan cuaca, tidak licin, tidak ada gundukan/sambungan pada lantai jika ada tidak boleh lebih dari 1,25 cm, tidak terhalang pohon/tiang, menghindari sambungan, lebar, tidak ada dan jika ada kemiringan harus sesuai standard dan terdapat pegangan/jalur khusus (di rumah sakit disebut dengan jalur Ramp) (Sary et al., 2018). Keamanan lingkungan harus diperhatian untuk menghindari risiko jatuh seperti tidak terdapat lantai licin, pencahayaan yang cukup, terdapat pegangan dan tidak terdapat tangga/pembatas ruangan (Setyarini, 2010). Berdasarkan hasil jawaban kuesioner responden diketahui adanya persamaan antara teori yang ada yaitu kondisi lingkungan tempat tinggal yang dilewati oleh kursi roda sebagian besar tidak terdapat tangga/pembatas lantai antar ruangan/jalan landai/jalan licin karena sebagian besar responden hanya menggunakan kursi roda di dalam rumah/ruangan sesuai dengan kuesioner item pertanyaan soal nomor 1 guna menghindari kondisi lingkungan/jalan yang tidak sesuai untuk dilewati kursi roda karena rata-rata di rumah kondisi lingkungannya sesuai untuk dilalui kursi roda seperti yang dipaparkan, alasan lainnya mungkin karena kurangnya pemahaman keluarga tentang pentingnya modifikasi lingkungan pada pengguna kursi roda, dan atau kurangnya dana untuk memperbarui kondisi lingkungan di luar rumah/ruangan agar sesuai untuk dilalui kursi roda. Modifikasi lingkungan penting dilakukan baik di lingkungan tempat tinggal maupun perawatan medis terutama pada penyandang disabilitas untuk memudahkan akses, meningkatkan kemandirian, mempertahakankan keselamatan, serta menghemat tenaga (Zein, 2019). Kondisi lingkungan bagi penyandang disabilitas (pengguna kursi roda, tuna netra, tuna rungu, tunagrahita) harus disesuaikan dengan setiap kebutuhannya terutama pada bagian desain dan fasilitas yang membutuhkan perhitungan khusus sesuai dengan kebutuhan penyandang disabilitas, sehingga membutuhkan biaya yang cukup banyak untuk merenovasi kondisi 
lingkungan agar sesuai terutama pada ruang terbuka (Sary et al., 2018).

\section{Kondisi dan kemampuan pengguna kursi roda \\ Peneliti menemukan seluruh responden} memiliki penyakit penyerta. Stroke dapat disebabkan oleh ruptur arteriosklerotik dan hipertensi yang mengakibatkan terjadinya stroke hemorragik, selain itu stroke juga dapat disebabkan oleh thrombus pada pembuluh darah/tertutupnya pembuluh arteri oleh bekuan darah, biasanya yang sering terjadi akibat adanya plak pada pembuluh darah biasanya sering terjadi pada penderita diabetes mellitus/berkurangnya aliran darah keseluruh tubuh akibat gangguan denyut jantung biasanya terjadi pada penderita gangguan pada jantung (Nurarif et al., 2015). Berdasarkan hasil jawaban kuesioner responden di lapangan diketahui adanya persamaan dengan teori yang ada yaitu penderita stroke memiliki penyakit penyerta kemungkinan penyakit penyerta yang dialami oleh penderita stroke juga disebabkan oleh gaya hidup yang kurang sehat dan atau disebabkan oleh usia. Lansia merupakan periode kemunduran fisik, kelemahan fungsi tubuh secara menyeluruh terutama fleksibilitas pembuluh darah sehingga mudah terkena penyakit degeneratif (Karunia, 2016). Penelitan ini tidak dilakukan wawancara atau survey lebih mendalam tentang jenis penyakit penyerta yang diderita responden dan alasan penyebab timbulnya penyakit penyerta karena penelitian ini berfokus pada penyebab terjadinya risiko jatuh pada penderita stroke pengguna kursi roda.

Peneliti menemukan bahwa hampir seluruh responden menyadari adanya hambatan atau kesulitan dalam berjalan/berpindah sesuai kuesioner item pertanyaan nomor 6 . Kondisi pasien stroke di rumah sakit bukan hanya di pantau kondisi fisiknya saja namun juga dilakukan pemantauan risiko jatuh, pasien stroke yang diperbolehkan dirawat di rumah dilihat dari membaiknya keadaan fisik dan kestabilan status mental seperti tidak mengalami disorientasi, menyadari kondisi dan kelemahannya saat ini, serta kemampuan keluarga dalam merawat pasien selama di rumah (Setyarini, 2010). Berdasarkan hasil survey di lapangan (peneliti melihat langsung kondisi klien stroke pengguna kursi roda) diketahui adanya persamaan dengan teori yang ada sehingga dapat menjadi penyebab kenapa responden menyadari adanya hambatan atau kesulitan dalam berjalan/berpindah karena responden yang mengalami stroke sebelumnya sudah mengalami perawatan rumah sakit sehingga ketika di pulangkan responden dapat berpikir, merasakan dan paham akan kondisinya yang kesulitan atau bahkan tidak dapat menggerakkan ekstremitasnya sebagai salah satu dampak dari penyakit strokenya. Pada pasien stroke yang mengalami hambatan mobilitas fisik disebabkan karena adanya gangguan pada sistem saraf pusat yang menyebabkan gangguan pada neuromuskular yang menyebabkan terjadinya gangguan gerak atau gangguan pada kekuatan ototnya dengan gejala klinis hemiparesis/hemiplegia yang merupakan salah satu faktor penyebab hilangnya mekanisme reflek posturnal normal tubuh, seperti mengontrol siku untuk bergerak, mengontrol gerak kepala, dan rotasi tubuh (Basuki, 2018). Hal inilah yang juga menyebabkan hampir seluruh responden tidak mampu/kesulitan menjangkau tuas rem yang ada di samping pada bagian roda saat menggunakan kursi roda sesuai kuesioner item pertanyaan soal nomor 8 dan tidak mampu/kesulitan mengayuh kursi roda secara mandiri sesuai kuesioner item pertanyaan soal nomor 9, sedangkan dari hasil survey di lapangan (peneliti melihat secara langsung kemampuan responden menjangkau tuas rem dan menjalankan kursi roda) terdapat sebagian kecil dari keseluruhan jumlah responden yang ada mampu menjangkau tuas rem dan mengayuh atau menjalankan roda pada kursi roda secara mandiri. Hal ini kemungkinan terjadi karena responden sudah hampir mengalami pemulihan atau bahkan sudah mengalami pemulihan pada tangannya. Kemandirian penderita stroke yang rajin melakukan latihan motorik akan lebih cepat mengalami pemulihan kondisi fisologisnya sehingga mengurangi tingkat ketergantungannya kepada keluarga dan dapat memenuhi kebutuhan dasar ADL seperti makan, minum, menggunakan alat bantu jalan dan membersihkan diri secara mandiri (Karunia, 2016). Penelitian ini tidak dilakukan wawancara dan survey lebih mendalam tentang alasan responden mampu atau tidak mampu/kesulitan dalam menjangkau tuas rem dan mengayuh atau menjalankan kursi roda secara mandiri, 
karena penelitian ini berfokus pada penyebab terjadinya risiko jatuh pada penderita stroke pengguna kursi roda.

Peneliti menemukan bahwa sebagian besar responden mampu memposisikan dan mempertahankan posisi tubuh dengan tepat saat duduk di kursi roda (kaki, tangan, bokong, dan punggung) sesuai kuesioner item pertanyaan soal nomor 7 . Kursi roda yang ada di desain khusus dan di sesuaikan untuk digunakan oleh penyandang cacat kaki/orang dengan ganguan mobilisasi untuk memberikan rasa nyaman dan aman bagi penggunanya terutama dibagian safety seperti terdapat tempat duduk dan sandaran punggung, pijakan kaki, penyangga kaki bagian belakang, dan tuas rem yang berada dibagian samping (Ayundyahrini et al., 2019). Berdasarkan hasil survey di lapangan (peneliti melihat secara langsung kemampuan penderita stroke mempertahankan posisi tubuhnya diatas kursi roda) diketahui adanya persamaan dengan teori yang ada sehingga dapat menjadi penyebab responden dapat memposisikan dan mempertahankan posisi tubuhnya saat duduk di kursi roda karena desain kursi roda yang ada mampu meminimalisir adanya perubahan posisi ketika digunakan seperti kaki terjatuh dari pijakan kursi roda, kondisi penderita stroke yang rata-rata mengalami hemiplegia sehingga otot dan tulang tubuh masih mampu untuk mempertahankan posisi, serta adanya bantuan dari orang lain (keluarga) selama penggunaan kursi roda seperti hasil survey yang tertera pada kuesioner item pertanyaan soal nomor 3 . Survey di lapangan juga didapatkan data bahwa hampir setengah dari seluruh reponden tidak mampu mempertahankan posisi tubuh di kursi roda, kemungkinan hal ini terjadi karena kurangnya perhatian dari keluarga dalam melatih kemampuan motorik responden sehingga semakin parahnya kondisi ekstremitas responden. Hambatan mobilitas ini jika dibiarkan akan menyebabkan atropi otot dan kelumpuhan permanen (Basuki, 2018) Penderita stroke membutuhkan dukungan keluarga untuk menerapkan dan memotivasi penderita stroke dengan hambatan mobilitas untuk melatih kemampuan motoriknya (Karunia, 2016).

Peneliti menemukan bahwa hampir seluruh responden tidak sering merasa lemah dan pusing saat berpindah dari tempat tidur ke kursi roda dan sebaliknya sesuai kuesioner item pertanyaan soal nomor 10, dan seluruh responden tidak pernah tertidur/bahkan pingsan saat sedang menggunakan kursi roda sesuai kuesioner item pertanyaan soal nomor 11 . Kondisi tubuh pengguna kursi roda yang menderita penyakit lebih dari satu (terdapat penyakit penyerta) yang dapat mempengaruhi kondisi fisik misalnya pada penderita penyakit stroke disertai diabetes melitus/penyakit jantung yang sewaktuwaktu bisa mengalami tidak sadarkan diri dan pada penderita stroke dengan hipertensi/ diabetes melitus ketika melakukan perubahan posisi dan aktivitas berlebih dapat menyebabkan tekanan darah menurun dan atau pusing mendadak (Dessy et al., 2013). Teori yang ada berbanding terbalik dengan hasil jawaban kuesioner responden mungkin karena responden sudah terbiasa menghadapi kondisi merasa lemah atau pusing secara mendadak atau bahkan merasa ngantuk sehingga ketika hal itu terjadi responden tidak akan pindah ke kursi roda atau jika berada di kursi roda akan segera meminta bantuan untuk dipidahkan ke tempat tidur dan karena hal inilah keluarga menjadi lebih memperhatikan kondisi anggota keluarganya yag mengalami stroke terutama saat melakukan mobilisasi. Penderita stroke membutuhkan waktu yang lama dalam pemulihan meskipun sudah dipulangkan dalam keadaan fisik dan mental yang stabil (Setyarini, 2010). Penerapan penggunaan alat bantu (tongkat, walkel, atau kursi roda) untuk berpindah diutamakan dilakukan ketika kondisi penderita stroke stabil (Pratama, 2020). Kondisi penderita stroke yang tidak pulih sepenuhnya masih membutuhkan bantuan keluarga dalam memenuhi ADL-nya, hal ini membuat keluarga serta penderitanya memahami dan beradaptasi dengan kondisi penyakit dan cara penanganan atau cara meminimalisir bila terjadi perburukan kondisi (Karunia, 2016). Berdasarkan hasil kuesioner item pertanyaan soal nomor 10 terdapat sebagian kecil dari keseluruhan responden yang ada sering merasa lemah dan pusing saat akan berpindah dari tempat tidur ke kursi roda dan sebaliknya. Hal ini tejadi kemungkinan karena responden dan atau keluarganya kurang mengetahui lebih dalam tentang penyakit stroke. Penderita stroke dan keluarganya harus memiliki pengetahuan yang cukup mengenai penyakit stroke, cara penanganan, perawatan di rumah, dukungan dan bantuan yang diperlukan guna 
memecahkan permasalahan yang kemungkinan akan terjadi pada penderita stroke itu sendiri atau keluarganya (Kosasih, Solehati, \& Purba, 2018).

\section{Riwayat jatuh}

Peneliti menemukan bahwa sebagian besar responden tidak pernah jatuh dan sebagian kecil pernah mengalami jatuh dari kursi roda dalam kurun waktu 3 bulan terakhir sesuai kuesioner item pertanyaan soal nomor 12. Risiko terjadinya jatuh disebabkan oleh kondisi tubuh yang sedang mengalami sakit terutama yang mengalami gangguan pada ekstremitas sehingga mengalami keterbatasan gerak, rata-rata yang mengalami risiko jatuh tinggi karena melakukan aktivitas sendiri tanpa meminta bantuan, tidak adanya penggunakan alat bantu untuk berjalan, kurangnya pengawasan, mengalami pusing/vertigo (Falls et al., 2013). Berdasarkan hasil jawaban kuesioner responden dan teori yang ada kemungkinan menjadi salah satu penyebab responden jatuh dari kursi roda yaitu bisa karena kurangnya pengawasan, adanya penyakit penyerta yang menyebabkan pusing mendadak seperti yang dipaparkan pada kuesioner item pertanyaan soal nomor 10. Responden tidak mengalami jatuh dari kursi roda kamungkinan disebabkan oleh beberapa alasan yang telah dipaparkan sebelumya seperti dibantu oleh keluarga saat menggunakan kursi roda saat berpindah dari tempat tidur ke kursi roda atau sebaliknya sesuai dengan kuesioner item pertanyaan nomor 3, tidak terdapat tangga/pembatas lantai antar ruangan/jalan landai/jalan licin yang sering dilewati ketika menggunakan kursi roda sesuai kuesioner item pertanyaan nomor 4 , dan sebaginya. Penelitan ini tidak dilakukan wawancara atau survey lebih mendalam tentang alasan kenapa responden ada yang mengalami jatuh dan tidak mengalami jatuh dari kursi roda dalam kurun waktu 3 bulan terakhir, karena penelitian ini berfokus pada penyebab terjadinya risiko jatuh pada penderita stroke pengguna kursi roda.

Gambaran risiko jatuh pada pengguna kursi roda di Kabupaten Pamekasan sebagian besar responden mengalami risiko rendah untuk jatuh dari kursi roda berdasarkan beberapa temuan hasil survey di lapangan sebagai berikut: responden tidak melakukan aktivitasnya di luar rumah dan tidak ke kamar mandi untuk buang air besar (BAB) dan atau buang air kecil (BAK), aktivitas responden dibantu oleh keluarga terutama saat berpindah dari tempat tidur ke kursi roda atau sebaliknya, kondisi lingkungan tempat tinggal yang dilewati oleh kursi roda sebagian besar tidak terdapat tangga/pembatas lantai antar ruangan/jalan landai/jalan licin, meskipun responden mengidap penyakit penyerta namun mampu menyadari adanya hambatan atau kesulitan dalam berjalan/berpindah dan mampu memposisikan dan mempertahankan posisi tubuh dengan tepat saat duduk di kursi roda (kaki, tangan, bokong, dan punggung), meskipun tidak mampu/kesulitan untuk mengoperasikan kursi roda secara mandiri seperti menjangkau tuas rem dan mengayuh atau menjalan roda, tapi tidak sering merasa lemah dan pusing saat akan berpindah dari tempat tidur ke kursi roda dan sebaliknya dan tidak pernah tertidur/bahkan pingsan saat sedang menggunakan kursi roda, serta tidak pernah jatuh dari kursi roda dalam kurun waktu 3 bulan terakhir.

\section{KESIMPULAN}

Sebagian besar klien stroke yang menggunakan kursi roda di Kabupaten Pamekasan mengalami risiko rendah untuk jatuh dari kursi roda.

\section{DAFTAR PUSTAKA}

Ambarwati, D. R. S. (2009). DESAIN INTERIOR RUMAH TINGGAL, 9-16.

Ayundyahrini, M., Suprapto, Anggraeni, putty, Fahma, F., \& Soetopo, W. (2019). Penerapan dan kemutakhiran sni 09-4663-1998 tentang kursi roda oleh pemangku kepentingan, 135-142.

Basuki, L. (2018). Penerapan Rom (Range of Motion) Pada Asuhan Keperawatan Pasien Stroke Dengan Gangguan Mobilitas Fisik Di Rsud Wates Kulon Progo.

Batan, I. M. L. (2006). Pengembangan Kursi Roda Sebagai Upaya Peningkatan Ruang Gerak Penderita Cacat Kaki. Pengembangan Kursi Roda Sebagai Upaya Peningkatan Ruang Gerak Penderita Cacat Kaki, 8(2), 97-105. https://doi.org/10.9744/jti.8.2.pp.9 7-105

Dessy, V. A., Hermayetty, \& Widyawati, I. W. (2013). Penilaian risiko jatuh usia (lansia) menggunakan pendekatan 
Hendrich falls scale dan Morse falls scale. Jurnal Ners.

Falls, H., Dan, S., Falls, M., Fall, E., Assessment, R., Scale, E., ... Scale, M. (2013). Penilaian risiko jatuh lanjut usia (lansia) menggunakan pendekatan. Jurnal Ners, 8(1), 107117.

Karunia., E. (2016). Hubungan antara dukungan keluarga dengan kemandirian Activity of Daily Living Pascastroke, (July), 213-224. https://doi.org/10.20473/jbe.v4i2.2 016.213

Kosasih, C. E., Solehati, T., \& Purba, C. I. (2018). Pengaruh Edukasi Kesehatan Terhadap Pengetahuan Pasien Stroke dan Keluarga: Peran, Dukungan, dan Persiapan Perawatan Pasien Stroke di Rumah. Media Kesehatan Politeknik Kesehatan Makassar, $13(2), \quad 8$. https://doi.org/10.32382/medkes.v $13 i 2.662$

Kurniasih, S., \& Pratama, I. M. J. (2020). Prototipe Jendela Kaca Untuk Ruang Berjemur Dalam Rangka Meningkatkan Imunitas Tubuh. Jurnal Arsitektur ARCADE, 4(3), 269. https://doi.org/10.31848/arcade.v4 i3.567

Nurarif, A. H., \& Kusuma, Ha. (2015). No TitleAplikasi Asuhan Keperawatan Berdasarkan Diagnosa Medis dan Nanda Nic-Noc (3rd ed.). Jogjakarta: MediAction.

Pratama, ferina nadya. (2020). Digital Digital Repository Repository Universitas Universitas Jember Jember Staphylococcus aureus Digital Digital Repository Repository Universitas Universitas Jember Jember. Skripsi.

Purwanggono, B., Inryani, E., \& Adi, P. (2008). Perawat Panti Wredha Semarang, III(3), 167-175.
RSUD Pamekasan. (2020). Laporan Tahunan Rumah Sakit Umum Daerah "Dr. H. Slamet Martodirdjo" Kabupaten Pamekasan Tahun 2020. Rumah Sakit Umum Daerah Dr. H. Slamet Martodirjo.

Sary, R. K., \& Kamil, E. M. (2018). Evaluasi Fasilitas Penunjang untuk Penyandang Disabilitas di Kawasan Benteng Kuto Besak Palembang. Arsir.

https://doi.org/10.32502/arsir.v2i1 .1237

Setyarini, E. A. (2010). Pelaksanaan standar prosedur operasional: Identifikasi resiko pasien jatuh dengan menggunakan skala jatuh morse di rumah sakit "a" Bandung. Stikes, 1, $1-12$.

Suhendro. (2014). PENGALAMAN PRIBADI MENGOBATI PENYAKIT STROKE, 10(1), 54-59.

Syakura, A., \& Sw, A. (2020). Self-care Management to Prevent Exacerbation for Patients with Chronic Obstructive Pulmonary Disease ( COPD ): A Systematic Review, 3(3), 391-401. https://doi.org/10.35654/ijnhs.v3i3 .228

Zein, A. O. S. (2019). Kemunduran Fisiologis Lansia dan Pengaruhnya Terhadap Keselamatan di Kamar Mandi Studi Kasus Kamar Mandi Panti Wredha Asuhan Bunda. Itenas Repository, 110. 